\title{
Spektroskopik Teknikler Kullanılarak Furosemid ile DNA Etkileşimlerinin İncelenmesi
}

\author{
Bahar YILMAZ* \\ Karamanoğlu Mehmetbey Üniversitesi, Mühendislik Fakültesi, Biyomühendislik Bölümü, Karaman \\ (ORCID: 0000-0002-6315-3018)
}

\begin{abstract}
$\ddot{\mathbf{O z}}$
İlaç-DNA etkileşiminin araştırılması, moleküler düzeyde ilaç etkisini anlamak ve spesifik DNA hedefli ilaç tasarlamak için önemlidir. Furosemid, diüretik adı verilen bir ilaç ailesindedir ve böbrek, kalp ve karaciğer hastalıkları dahil olmak üzere çeşitli tıbbi sorunların neden olduğu ödemin tedavisinde kullanılır. DNA'nın Furosemid ile etkileşimi absorpsiyon, emisyon, Fourier dönüşümü kızılötesi spektroskopik (FTIR) teknikler ve agaroz jel elektroforezi ile analiz edilmiştir. FTIR sonuçları, Furosemid'in guanin ve sitozin nitrojen bazları ile bağlanmasının yanı sıra DNA şeker-fosfat omurgası ile zayıf teması gösterir. Furosemid'in DNA ile etkileşiminin UV, floresans spektroskopi ve agaroz jel elektroforezi çalışmaları, DNA'ya bağlanabildiğini göstermiştir. Bu sonuçlar, Furosemid ilaç molekülünün başta kanser hatalıkları olmak üzere DNA temelli birçok hastalığın tedavisinde kullanılabileceğini göstermektedir.
\end{abstract}

Anahtar kelimeler: Furosemid, İlaç-DNA etkileşimi, FTIR spektroskopisi, UV spektroskopisi, Floresans spektroskopisi

\section{Study of Interactions of Furosemide with DNA Using Spectroscopic Techniques}

\begin{abstract}
Investigation of drug-DNA interaction is important for understanding the drug action at molecular level and for designing specific DNA targeted drug. Furosemide is in a family of medicines called diuretics and is used for the treatment of edema caused by various medical problems, including diseases of the kidneys, heart and liver. The interaction of DNA with Furosemide has been analyzed by absorption, emission, Fourier transform infrared spectroscopic (FTIR) and agarose gel electrophoresis. Results of FTIR indicate binding of Furosemide with guanine and cytosine nitrogen bases along with poor contact with the DNA sugar-phosphate backbone. UV, fluorescence spectroscopy and agarose gel electrophoresis studies of the interaction of Furosemide with DNA have shown that it can binds to DNA. These results show that the Furosemide drug molecule can be used in the treatment of many DNA-based diseases, especially cancer diseases.
\end{abstract}

Keywords: Furosemide, Drug-DNA interaction, FTIR spectroscopy, UV spectroscopy, Fluorescence spectroscopy

\section{Giriş}

Furosemid ödem tedavisinde kullanılan antranik asit türevi olan idrar söktürücüdür. Furosemid, beyazımsı yapıya sahip kokusuz kristal bir tozdur (Şekil 1). Yüksek tansiyon tedavisinde kullanılabilir ve vücudun aşırı tuz emmesini önler [1]. Aynı zamanda konjestif kalp yetmezliği, karaciğer hastalığı veya nefrotik sendrom gibi böbrek rahatsızlığı bulunan kişilerde sıvı tutulumunu (ödem) tedavi etmek için kullanılır. Furosemid ayrıca karaciğer sirozu, böbrek yetmezliği, nefrotik sendrom için, hızlı diürezin gerekli olduğu beyin veya akciğerlerin şişmesi için yardımcı tedavide ve yeterli rehidrasyon ile birlikte şiddetli hiperkalseminin tedavisinde kullanılır [2, 3].

*Sorumlu yazar: bahar.kmu@gmail.com

Geliş Tarihi: 08.01.2021, Kabul Tarihi: 21.03.2021 


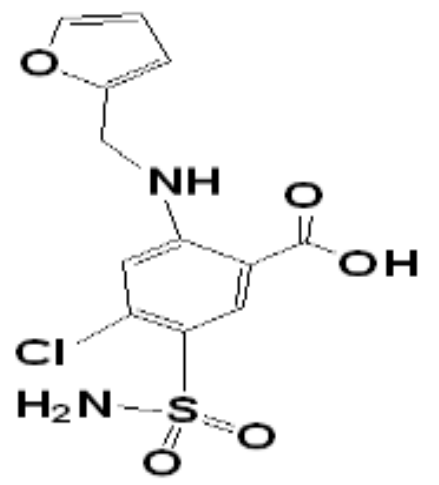

Şekil 1. Furosemid'in kimyasal yapısı

Deoksiribonükleik asit (DNA), yaşam sürecinde önemli bir rol oynar. Canlı hücrelerde genetik bilginin kopyalanması ve taşınmasını sağlar $[4,5]$. Ayrıca transkripsiyon yoluyla proteinlerin ve enzimlerin biyolojik sentezini yönlendirir. Bazı küçük moleküllerin DNA ile bağlanma mekanizması üzerine yapılan çalışmalar, geçtiğimiz birkaç on yılda anahtar konulardan biri olarak belirlenmiştir [6]. Dahası, DNA'nın yapısal özelliklerini, genlerin mutasyonunu, bazı hastalıkların kökenini, bazı antitümör ve antivirüs ilaçlarının etki mekanizmasını anlamak ve bu nedenle başa çıkmak için yeni ve daha etkili DNA hedefli ilaçlar tasarlamak birçok hastalıkla başa çıkmakta çok yardımcı olacaktır [7].

Kontrolsüz bölünmeler nedeniyle oluşan kanser hastalı̆ğ başta olmak üzere birçok DNA temelli hastalık bulunmaktadır. DNA temelli hastalıklar, hücre çoğalması, dokularda yenilenme ve onarım amacıyla meydana gelmektedir [8]. Bu hatalıkların oluşumundaki temel sebep, hatalı DNA replikasyonlarından kaynaklı hücre bölünmeleridir. Bu nedenle DNA'nın kimyasal bazı moleküllerle etkileşmesi ve bu etkileşmelerin tayin edilebilmesi, kanser tedavisi başta olmak üzere birçok DNA temelli hastalıklarda yeni ilaçların geliştirilmesi açısından önemlidir [8, 9]. Örneğin birçok kanser ilacı DNA moleküllerini etkiler ve bu etkileşim DNA-ilaç kompleklerini oluşturur. Son zamanlarda DNAilaç etkileşimlerni incelemek için spektroskopik, elektrokimyasal ve kromotografik yöntemler kullanılmaktadır. Bu yöntemler ile DNA ve ilaç molekülleri arasındaki etkileşimlerin kovalent veya kovalent olmayan bağlarla, içerdikleri gruplar ve konformasyonlarla nasıl gerçekleştirildiği saptanmaktadır [10].

İlaç molekülleri, DNA ile kovalent veya kovalent olmayan etkileşimler yoluyla bağ kurabilir. DNA molekülünde bu tür bir bağlanmanın meydana gelebileceği birkaç bölge vardır. Bunlar; iki baz çifti arasında (tam interkalasyon), küçük olukta, ana olukta, dış tarafta sarmal yapıda ve elektrostatik bağlama olarak gerçekleşebilir [10]. İlaçların geliştirilmesi yavaş ve maliyetli bir süreçtir. Bu nedenle Furosemid gibi bazı ilaçların biyolojik bileşiklerle moleküler benzerliğe sahip ve DNA ile etkileşim gösterebileceği gibi yaklaşımlar onaylanmış birçok ilaçları yeniden konumlandırmaktadır [8].

Bu çalışmada, diüretik bir ilaç olan Furosemid'in DNA ile etkileşmeleri hakkında kaynaklarda yeteri kadar çalışmaya rastlanmadığı için bu ilacın DNA ile etkileşmelerinin spektroskopik ve elektroforez yöntemlerle incelenmesi amaçlanmıştır. Bu ilaç molekülünün DNA yapısını nasıl etkilediği absorbans ve emisyon spektrumları ile belirlenmeye çalışıldı ve bu etkileşimler DNA moleküllerinin jel görüntüleri ile ayrıca desteklenmeye çalışılmıştır. Bu nedenle Furosemid gibi DNA ile etkileşim sağlayarak DNA yapısına etki eden ilaç moleküllerinin etki mekanizmaları detaylı bir şekilde çalışılmış ve rapor edilmiştir.

\section{Materyal ve Metot}

\subsection{Materyal}

Yüksek derecede polimerize edilmiş çift zincirli DNA molekülü (Buzağ1 timus bezinden elde edilen DNA (= Calf Thymus DNA)), Furosemid ilaç molekülü ve tampon çözelti malzemeleri Merck ve Sigma-Aldrich'den temin edildi. Tris- $\mathrm{HCl}$ tampon ( $\mathrm{pH}$ 7.4) ve tüm çözeltiler distile su kullanılarak hazirlandi.

DNA'nın stok çözeltisi, Tris- $\mathrm{HCl}$ tamponu içinde çözülerek hazırlandı ve $4{ }^{\circ} \mathrm{C}$ 'de saklandı. Bir DNA çözeltisi 260 ve $280 \mathrm{~nm}$ 'de 1.8'den daha fazla bir UV soğurma oranı vermiştir, bu da DNA'nın 
proteinden yeterince arınmış olduğunu göstermektedir. Proteinden yeterince arınmış olarak elde edilen DNA molekülü deney için kullanıma uygun bulunmuştur. DNA molekülünün konsantrasyonu, 260 nm'de molar absorpsiyon katsayısı kullanılarak UV absorpsiyon spektroskopisi ile ölçülerek belirlendi. Suda çözünürlüğü düşük olan Furosemid ilaç molekülünün stok çözeltisi, asetonda bir miktar ilaç çözümü gerçekleştirildi ve son hacim Tris- $\mathrm{HCl}$ tamponu ile $1.10^{-3} \mathrm{M}$ olacak şekilde tamamlandı.

\subsection{FTIR spektroskopisi}

FTIR spektroskopisi, Furosemid ilaç molekülünü, çift zincirli DNA molekülünü ve Furosemid-DNA kompleksinin olası etkileşimlerini kanıtlamak için $4000-400 \mathrm{~cm}^{-1}$ arasında taramalar gerçekleştirilmiş ve yapılan taramalar ile elde edilen spektrumlar rapor edilmiştir [10].

\subsection{UV ve Floresans spektroskopisi}

DNA-Furosemid etkileşimleri için UV-Vis spektrumları, bir Shimadzu UV 1800 kullanılarak elde edildi. DNA ve Furosemid solüsyonları $1 \mathrm{~cm}$ 'lik kuvars küvet içinde ölçülerek kaydedildi. Emilim deneyleri, DNA $(100 \mu \mathrm{M})$ konsantrasyonu sabit tutulup ilaç konsantrasyonu (100-1000 $\mu \mathrm{M})$ arasında değiştirilerek ölçüldü ve absorbans değerleri kaydedildi.

Floresan ölçümleri, bir Hitachi F-7100 ile gerçekleştirildi. DNA ve Furosemid arasındaki etkileşim için, $340 \mathrm{~nm}$ dalga boyunda uyarım yapılmış $420 \mathrm{~nm}$ 'de floresans yoğunluğu alınmıştır ve rapor edilmiştir [11, 12].

\subsection{Furosemid'in DNA ile etkileşiminin tespiti}

Furosemid ilaç molekülünün $(100-1000 \mu \mathrm{M})$ DNA $(100 \mu \mathrm{M})$ üzerinde etkisi araştırılmıştır. Farklı konsantrasyondaki Furosemid molekülü DNA ile inkübe $\left(24\right.$ saat, $37^{\circ} \mathrm{C}$ 'de) edilmiştir. İnkübasyon sonrası elektroforezde yürütülüp ortaya çıkan bantlar izlenmiştir.

\subsection{Agaroz jel elektroforezi}

İnkübe edilen DNA ve farklı konsantrasyonlardaki Furosemid molekülleri jelde elektrik akımı altında yürütülmüştür. \%1'lik TBE tamponu $\left(50 \mathrm{mM} \mathrm{H}_{3} \mathrm{~B}_{3}\right.$, 50mMTris, 1 mM-EDTA ve pH 7.2) tampon çözelti olarak hazırlanmıştır ve etidyum bromür $(0,5 \mu \mathrm{g} / \mathrm{mL})$ ile boyama işlemi gerçekleştirilmiştir. Hazırlanan agaroz jel soğutularak $\left(55^{\circ} \mathrm{C}\right.$ 'ye kadar) yükleme için DNA kuyucukları oluşturmak üzere taraklar yerleştirildikten sonra jel tabağına kabarcıklar olmayacak şekilde dökülmüştür. Polimerizasyon gerçekleşmesi için 45-50 dakika oda sıcaklığında bekletilmiştir. Polimerizasyonu gerçekleştirilen jel elektroforez tankına alındıktan sonra, TBE 1X tamponu ile jelin üstü kapanacak şekilde elektroforez tank1 dolduruldu. Örnekler jel kuyucuklarına yüklendi ve yürütüldü ( $80 \mathrm{~V}, 60$ dakika). Yürütme işlemi bitince, görüntüleme cihazı ile DNA fragmanları görüntülendi ve jellerin fotoğrafları çekildi [4].

\section{Bulgular ve Tartışma}

FTIR, boyutu küçük biyomoleküllerin yapısının aydınlatılmasından tıbbi teşhise kadar değişkenlik gösteren birçok uygulamalarla yaşam genelinde son zamanlarda oldukça etkili bir cihaz olarak keşfedildi. Aynı zamanda bu araç, ilaç-biyomolekül veya ilaç-makromolekül etkileşimlerinde de yapının karekterizasyonu için önemli bir yöntem olarak düşünülmüştür.

FTIR çalışması, Furosemid bağlanması üzerine DNA'nın yapısal özelliklerindeki değişiklikleri anlamak için yapıldı. DNA-ilaç komplekslerinin oluşturduğu yeni spektrumlar, Furosemidin DNA'ya bağlandığını gösteren bir kanıt olarak rapor edildi. Serbest Furosemid, serbest DNA ve Furosemid-DNA etkileşiminin FTIR spektrumları Şekil 2'de gösterilmiştir.

Serbest DNA' nın amino grubunun (NH) oluşturduğu geniş pik 3550-3000 $\mathrm{cm}^{-1}$ civarında ortaya çıkmıştır. Furosemid bağlanması ile oluşan Furosemid-DNA kompleksi ise $3700-2900 \mathrm{~cm}^{-1}$ civarında daha geniş bir pik ortaya çıkarmıştır. Bu açıkça, serbest DNA'nın amino grubundan sorumlu olan bandın, ilaç kompleksleşmesi üzerine genişlediğini göstermiştir. NH bandının ilaç molekülleri ile elde edilen komplekslerde meydana gelen genişlemeler, Johnson ve arkadaşlarının yaptığı çalışmada olduğu gibi, 
esas olarak ilaçların DNA bazları ile H-bağı oluşturarak etkileşime girdiğini ifade etmektedir. Furosemid ilaç molekülünün farklı noktalarda $\left(1669,1591,1561,1491,1451,1406,1318,1230\right.$ ve $\left.1140 \mathrm{~cm}^{-1}\right)$ verdiği pikler ve DNA'nın $1637,4 \mathrm{~cm}^{-1}$ civarında verdiği karbonil $(\mathrm{C}=\mathrm{O})$ pikinin titreşim frekansının ortadan kaybolduğu gözlenmiştir. Ardından yeni bir titreşim bandının $1700 \mathrm{~cm}^{-1}$ civarında ortaya çıkması DNA-Furosemid etkileşiminden kaynaklandığını göstermektedir. Bu durum, Furosemid ve DNA'nın $\mathrm{C}=\mathrm{O}$ ve NH gruplarının, H-bağ etkileşimine etkin bir şekilde dâhil olduğunu göstermektedir.

Furosemid'in DNA bazları (G-C / A-T) ile H-bağlanma etkileşimi, 1707-1400-1200 cm-1 civarında DNA yapısının düzlem içi titreşimlerinin ana spektral değişiklikleri ile doğrulanmaktadır. Esas olarak DNA yapısındaki guanin ve timin bazları $1695 \mathrm{~cm}-1(\mathrm{G}, \mathrm{T})$ civarında pik verirken, Furosemid ile kompleksleştikten sonra pik 1707 cm-1 civarına kaymıştır. İlaç kompleksleşmesine bağlı olarak bazların titreşim frekansındaki değişim, Furosemid'in A-T ve G-C bazları ile etkileşime girebildiğini açıkça göstermiştir.



Şekil 2. DNA, Furosemid ve DNA-Furosemid kompleksinin FTIR spektrumları $\left(4000-400 \mathrm{~cm}^{-1}\right)$

Furosemid ilaç molekülünün DNA hedef bölgesi için bağlanma ilgisinin karakterize edilmesi, ilaç etkinliğinin önemini arttırmaktadır. Yani Furosemid-DNA kompleksinin oluşmasına olanak sağladığı için önemli bir durumdur. Bu durumu desteklenmek üzere Furosemid molekülünün DNA'ya bağlanması UV-vis spektroskopisi ile incelenmiştir.

Saf DNA molekülünün farklı konsantrasyonlardaki $(50,100,200,400,500$ ve $1000 \mu \mathrm{M})$ absorbans değeri $260 \mathrm{~nm}$ 'de doğru orantılı bir şekilde artış göstermiştir (Şekil 3a). Sabit konsantrasyondaki DNA molekülünün $(100 \mu \mathrm{M})$ farkl1 konsantrasyonlardaki Furosemid ilaç molekülü (100-1000 $\mu \mathrm{M})$ ile absorpsiyon spektrali Şekil 3b' de gösterilmektedir. Furosemid molekülü 240 ve 340 $\mathrm{nm}$ civarında belirgin pikler gösterirken, DNA molekülü $260 \mathrm{~nm}$ 'de belirgin bir pik göstermektedir. Sabit tutulan DNA molekülü üzerine Furosemid ilave edilmesi ile $260 \mathrm{~nm}$ 'de bulunan pik yoğunluğunda artış meydana (hiperkromik değişim) gelmiştir. 240 ve $340 \mathrm{~nm}$ 'de bulunan piklerde hiperkromik değişimler gözlemlenirken, $260 \mathrm{~nm}$ 'de hem hiperkromik hem de batokromik değişimler meydana gelmiştir (Şekil 3b). DNA spektrumlarında meydana gelen belirgin kaymalar (260'dan 270'e), Bayrakcı ve Yılmaz'ın yapmış olduğu DNA etkileşim çalş̧malarıyla örtüştüğünden dolayı DNA-Furosemid kompleksi arasında meydana gelen etkileşimi desteklemiştir. Meydana gelen hiperkromik kaymalar, DNA'nın ikincil yapısının kırıldığını, batokromik bir kaymanın gözlenmesi ise DNA ve Furosemid arasında interkalasyon olduğunu açıklamıştır. 

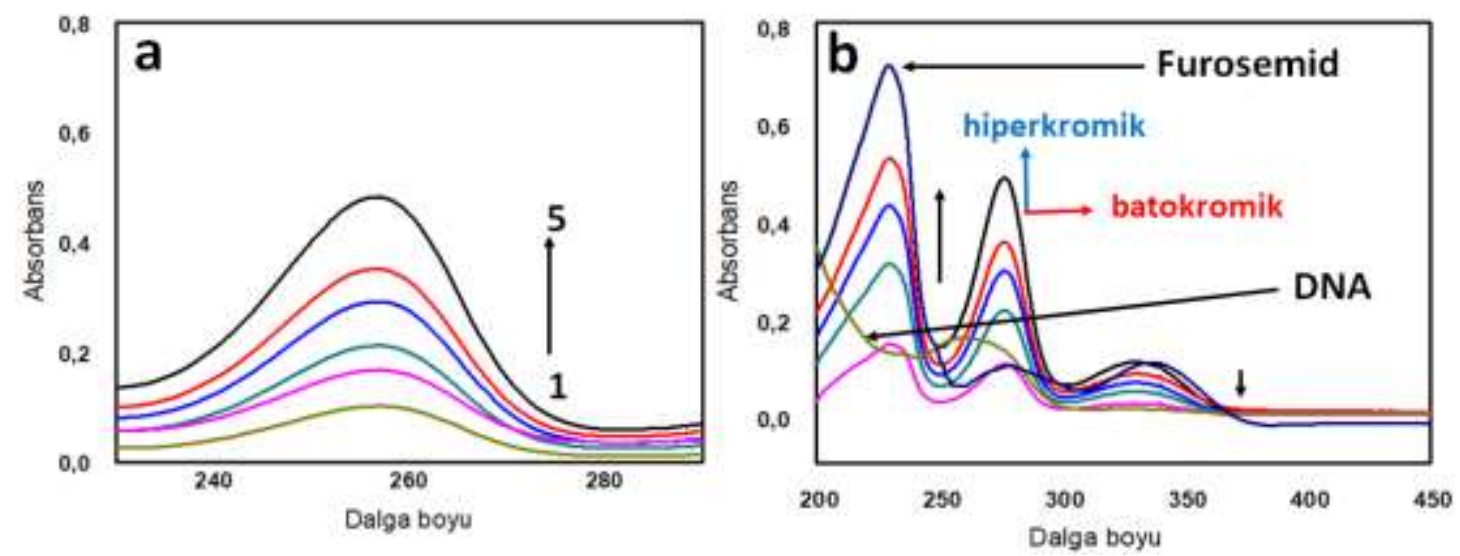

Şekil 3. DNA'nın artan derişimlerdeki (50-1000 $\mu \mathrm{M})$ UV spektrumları (a) $100 \mu \mathrm{M}$ DNA çözeltisi üzerine (100$1000 \mu \mathrm{M}$ ) Furosemid eklenmesi ile 200-600 nm arasinda elde edilen UV spektrumları (b)

Furosemid, interkalasyonu gerçekleştirmek için yapısında bulunan aromatik halka, klasik interkalatif etkileşimine katkı sağlamıştır. Ek olarak, bu ilaç molekülü düşük bağlanma boyutuna sahip küçük bir moleküldür. Bu nedenle küçük oluk bağlanması, majörden daha çok tercih edilir ve genellikle AT'nin uzantıları ve 2-amino grubu (NH) için küçük DNA oluğuna bağlanma tercihine sahiptirler. Johnson ve arkadaşlarının yaptığı çalışma ile paralellik gösteren bu çalışma doğrultusunda ortaya çıkan kaymalar Furosemid molekülünün DNA yapısının amin gruplarına ilgi duyabileceği kanıtlamıştır. Furosemid-DNA arasında meydana gelen bu absorbans değişimlerini emisyon spektrumlarıyla da destekleyebilmek için floresans ölçümleri alınmıştır.

Furosemid' in DNA'yı interkalatif mod ile bağlaması floresans ölçümlerde de görülen floresans prob ile kanıtlanmıştır. DNA yokluğunda ve varlığında Furosemid emisyon spektrumları Şekil 4'te gösterilmiştir. Şekil 4'te gösterildiği gibi, 340 nm'de uyarılan dalga boyu ile Furosemid maksimum emisyon dalga boyu $420 \mathrm{~nm}$ olarak belirlendi. Furosemi'in emisyon yoğunluğu, DNA molekülü eklenmesi üzerine $420 \mathrm{~nm}$ 'den $460 \mathrm{~nm}$ 'ye belirgin bir kayma ile sonuçlandı. Furosemid'in DNA molekülü eklenmesi üzerine meydana gelen kaymanın yanısıra emisyon yoğunluğundaki azalma, DNA molekülünün Furosemid ilaç molekünün floresans özelliğini baskıladığını göstermiştir. Artan DNA konsantrasyonu ile $460 \mathrm{~nm}$ 'de meydana gelen kompleks yapının floresans değeri ters orantılı olarak azalma göstermiştir (Şekil 4b).

Bu floresans yoğunluğunun değişmesinin iki olası nedeni vardır. İlk olarak, Furosemid ve DNA arasındaki bağlanma ilaç molekülünün DNA moleküleri arasına girerek meydana gelebilir ve ilaç molekülünün floresans yoğunluğu azalabilir. İkinci olarak, Furosemid DNA ile dışardan bağlanma gerçekleştirir ve DNA Furosemid ilaç molekülünün floresans gruplarını etkileyerek emisyon yoğunluğunun azalmasına sebep olabilir.

Furosemid molekülünün gösterdiği floresans özelliğin azalıp kayması DNA molekülünün ise değişmeyip hatta artış göstermesi Furosemid molekülünün DNA molekülü yapısına girdiği veya floresans özelliğe sahip bölgesinin DNA ile etkileşime girerek baskılandığı ifade edilmiştir.
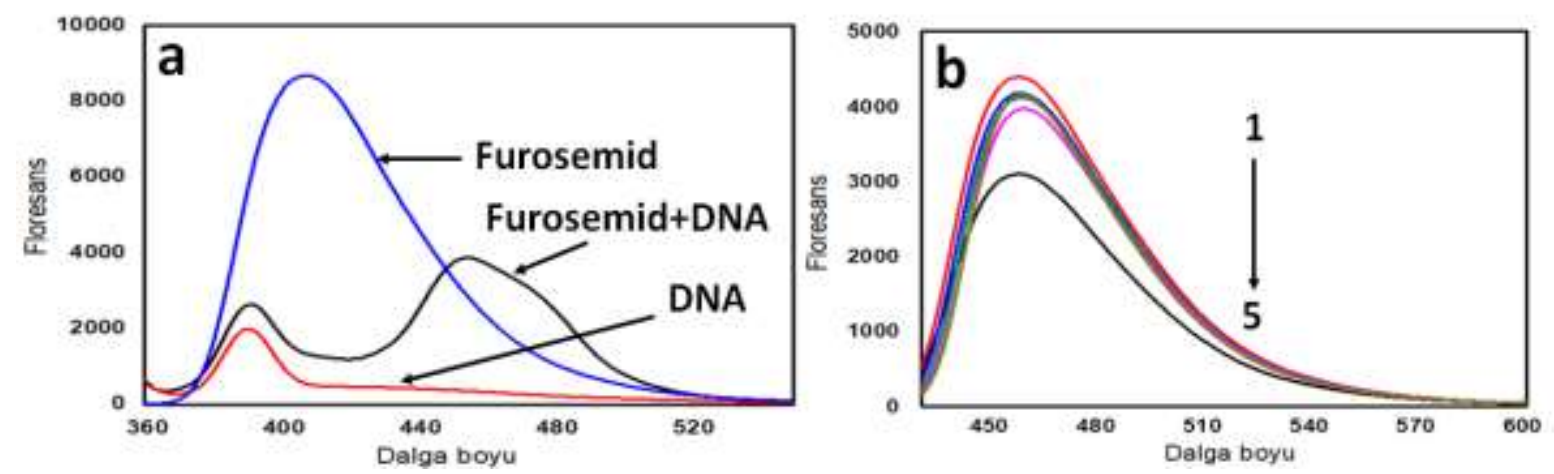

Şekil 4. DNA, Furosemid ve DNA-Furosemid kompleksi emisyon spectrumları (a) Furosemid (100 $\mu \mathrm{M})$ ile artan DNA konsantrasyonunun $(100-1000 \mu \mathrm{M})$ emisyon spektrumları (b) 
UV ve floresans sonuçları ile elde edilen DNA ve Furosemid arasındaki etkileşimleri desteklemek amaciyla son olarak agaroz jel elektroforez (\%2'lik agaroz) yöntemi ile görselleştirilerek açıklanmıştır. Farklı konsantrasyonlardaki Furosemid ilaç molekülü (100-1000 $\mu \mathrm{M})$ solüsyonları hazırlandıktan sonra $100 \mu \mathrm{M}$ DNA ile inkübe edilmiştir. İnkübasyon sonrası DNA-Furosemid etkileşimleri agaroz jel elektroforezinde yürütülerek aralarındaki etkileşim gözlenmiştir. Şekil 5 'te de görüldüğ̈̈ üzere ilaç konsantrasyonu arttıkça jelde görüntülenen DNA fragmanlarında daha soluk görüntüler elde edilmiştir. Bunun nedeni Furosemid ilaç molekülünün DNA yapısına bağlanması ya da ilgisinden dolayı DNA molekülünün jel içerisinde yürümesinin engellenmesinden kaynaklanmaktadır. DNA molekülleri jel elekteroforezi içerisinde molekül ağıllıklarına göre hareket ettiklerinden dolayı ilaç molekülleri ile etkileşime giren DNA yapıları porlardan geçmekte zorlandıkları için görüntülerde daha az konsantre DNA molekülleri gözlenmiştir.

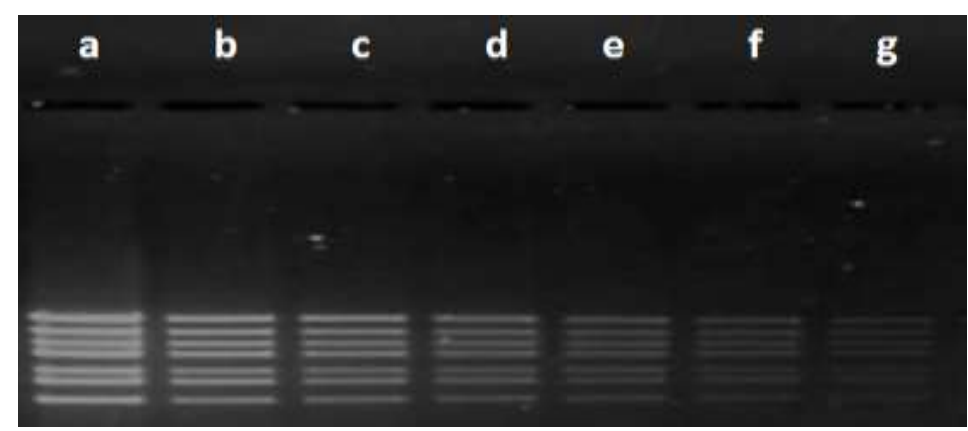

Şekil 5. Agaroz jel elektroforezi ile DNA ve Furosemid arasındaki ilişkinin görüntülenmesi. DNA (a) DNA-100 $\mu \mathrm{M}$ Furosemid (b) DNA-200 $\mu$ M Furosemid (c) DNA-300 $\mu$ M Furosemid (d) DNA-400 $\mu$ M Furosemid (e) DNA-500 $\mu$ M Furosemid (f) DNA-1000 $\mu$ M Furosemid (g)

\section{Sonuç ve Öneriler}

Kanser, kalp hastalıklarından sonra en çok ölümle sonuçlanan hastalıklardan biri olarak bilinir. Aşırı hızlı çoğalan hücrelerden dolayı oluşan bu hastalıklarının tedavisinde asıl amaç, kontrolsüz çoğalan hücrelerin baskılanmasıdır. Kanser oluşumunun başlıca nedeni DNA moleküllerinin hatalı replikasyonu sonucu hücrelerin kontrolsüz çoğalmasıdır. Tedavi için genellikle DNA çoğalmasını engellemek amaçlı ilaçlar tasarlanmaktadır. Bu nedenle DNA molekülü ile etkileşebilen ilaç molekülleri, ilaç etken maddeleri, metal yapılar ve çevresel atıklar gibi kimyasal maddeler tedavi yöntemlerini geliştirmek için oldukça önemlidir. Birçok farmakolojik çalışmalarda tasarlanan bu tür yapıların, DNA-ilaç etkileşmelerini araştırmak için, çoğunlukla elektrokimyasal ve spektroskopik çalımalar yapılmasının yanında, kromatografik metotlardan da yararlanılmaktadır.

Bu çalışmada, Furosemid ve DNA arasındaki etkileşimler, FTIR ölçümleri ile birlikte UV ve floresans spektroskopik teknikler kullanılarak araştırıldı. Ayrıca, Furosemid'in DNA'ya yüksek afinite ile bağlanabildiği agaroz jel elektroforez ile gösterildi. UV spektrumunun analizi ile, Furosemid'in DNA'ya bağlanırken baz çiftlerine veya amin gruplarına etkisi olduğu gözlemlendi. Furosemid ve DNA arasındaki etkileşimin esas olarak hidrofobik etkileşimleri ve hidrojen bağlarını içerdiği belirlendi.

Dolayısı ile bu çalışma, Furosemid'in DNA ile bağlanma mekanizmasını anlamak, DNA'yı hedefleyen yeni ve etkili ilaç moleküllerinin yapısını tasarlamak için daha ileri gitmemize yardımcı olabilir. Daha sonraki çalışmalarda ise, DNA temelli başta kanser hastalıkları olmak üzere birçok hastalığın tedavisinde bu tür ilaçların kullanılıp kullanılamayacaklarının incelenip araştırılmasına yönelik bir çalışmanın ortaya çıkma potansiyeli gerçekleşebilir.

\section{Yazarların Katkısı}

$\mathrm{Bu}$ makaledeki tüm katkı yazara aittir.

\section{Çıkar Çatışması Beyanı}

Yazarlar arasında herhangi bir çıkar çatışması bulunmamaktadır. 


\section{Araştırma ve Yayın Etiği Beyanı}

Yapılan çalışmada araştırma ve yayın etiğine uyulmuştur.

\section{Kaynaklar}

[1] Braler D.C. 1986. Drug-Drug and Drug-Disease Interacllons with Nonsteroidal AntiInllammatory Drugs. Am. J. Med., 80 (Suppl 1A): 62-77.

[2] O'Grady S.M., Musch M.W., Field M. 1990. Diüretic Compounds Structurally Relaled lo Furosemide. Methods in Enzym., 191: 781-792.

[3] Ujhely M. 1991. loop Diürelics: A Practical Guide to Their Use and Selection. Conn. Med., 55 (3): 162-165.

[4] Bayrakcı M., Yılmaz B. 2019. DNA ile Bağlanabilen Suda Çözünür Sülfonato Kaliks [8] Aren Sentezi ve Antimikrobiyal Aktivitesi. Niğde Ömer Halisdemir Üniversitesi Mühendislik Bilimleri Dergisi, 8 (1): 615-620.

[5] Atmaca L. 2020. Antineoplastik İlaçların DNA ile Etkileşmelerinin UV-Görünür Bölge Spektroskopisi ile İncelenmesi. Yüksek Lisans Tezi, Hacettepe Üniversitesi, Sağlık Bilimleri Enstitüsü, Ankara.

[6] Kashanian S., Khodaei M. M., Pakravan P. 2010. Spectroscopic studies on the interaction of isatin with calf thymus DNA. DNA and Cell Biology, 29 (10): 639-646.

[7] Afrin S., Rahman Y., Sarwar T., Husain M.A., Ali A., Tabish M. 2017. Molecular spectroscopic and thermodynamic studies on the interaction of anti-platelet drug ticlopidine with calf thymus DNA. Spectrochimica Acta Part A: Molecular and Biomolecular Spectroscopy, 186: 66-75.

[8] Shahabadi N., Hadidi S. 2012. Spectroscopic studies on the interaction of calf thymus DNA with the drug levetiracetam. Spectrochimica Acta Part A: Molecular and Biomolecular Spectroscopy, 96: 278-283.

[9] Fritzsche H., Akhebat A., Taillandier E., Rippe K., Jovin T.M. 1993. Structure and Drug interaction of parellel-stranded DNA studies by infrared spectroscope and fluorence. Nucleic Acids Research, 21 (22): 5085-5091.

[10] Johnson I.M., Prakash H., Prathiba J., Raghunathan R., Malathi R. 2012. Spectral analysis of naturally occurring methylxanthines (theophylline, theobromine and caffeine) binding with DNA. PLoS One, 7 (12): e50019.

[11] Bayrakcı M., Yılmaz B. 2019. Biyoaktif Giemsa Boyama Ajanı ile Suda Çözünen Sulfonato Kaliksaren Moleküllerinin Etkileşiminin Spektrofotometrik Olarak İncelenmesi. Iğdır Üniversitesi Fen Bilimleri Enstitüsü Dergisi, 9 (2): 985-992.

[12] Bayrakcı M., Yilmaz B. 2018. Intermolecular interactions and binding mechanism of inclusion complexation between sulfonate calix [n] arenes and ethidium bromide. Journal of Inclusion Phenomena and Macrocyclic Chemistry, 90 (3-4): 341-349. 